\title{
DETEKSI SEL MALARIA PADA SEDIAAN APUS DARAH BERDASARKAN FITUR MORFOLOGI DAN TEKSTUR MENGGUNAKAN JARINGAN BACKPROPAGATION
}

\section{MALARIA CELL DETECTION OF BLOOD APPLICATION PREPARATION BASED ON MORPHOLOGY AND TEXTURE FEATURES USING BACKPROPAGATION NETWORK}

\author{
Mustamin Hamid ${ }^{1}$, M Dzikrullah Suratin ${ }^{2}$, Alfanugrah A Hi Usman ${ }^{3}$ \\ 1,2,3Fakultas Teknik, Program Studi Teknik Informatika \\ ${ }^{1,2}$ Universitas Muhammadiyah Maluku Utara, ${ }^{3}$ Universitas Khairun \\ Email: hamidmustamin@gmail.com
}

\begin{abstract}
Abstrak
Sampai saat ini malaria masih menjadi masalah kesehatan di seluruh dunia yang mempengaruhi tingginya angka kematian bayi, balita dan ibu hamil. Data Dinas Kesehatan Maluku Utara tahun 2015, memberikan gambaran dari 10 kabupaten dan kota yang ada di Maluku Utara ditemukan kasus malaria klinis sebanyak 24.331 dan positif malaria setelah dilakukan pemeriksaan mikroskopis adalah 2.938. Hal ini Menunjukan Maluku Utara merupakan daerah yang menyumbang kasus malaria bagi Indonesia. Wilayah di Maluku Utara telah bertekad untuk eliminasi malaria salah satunya adalah Kota Tidore Kepulauan, namun pada tahun 2015 masih ditemukan kasus malaria sebanyak 229. Sehingga penelitian ini bertujuan untuk mendeteksi sediaan apus darah agar dapat mengenali fase malaria. Metode yang digunakan terdiri dari preprocessing yakni cropping citra, segmentasi untuk mempartisi warna latar pada citra, ekstraksi fitur morfologi dan tekstur untuk menentukan nilai citra dan klasifikasi backpropagation untuk mengenali fase citra malaria. Hasil dari pengenalan berdasarkan gabungan kedua fitur sebesar $85,56 \%$.
\end{abstract}

\section{Kata Kunci: Preprocessing, Segentasi, Ekstraksi Fitur, Backpropagation}

\begin{abstract}
Until now, malaria is still a health problem globally, which affects the high mortality rate for infants, toddlers, and pregnant women. North Maluku Health Office data for 2015 provides an overview of 10 districts and cities in North Maluku where 24,331 clinical malaria cases were found and malaria positive after the microscopic examination was 2,938. This shows that North Maluku is an area that contributes to malaria cases for Indonesia. The location in North Maluku has been determined to eliminate malaria, one of which is the City of
\end{abstract}


Tidore Islands, but in 2015 there were still 229 cases. So this study aims to detect blood smears so that they can recognize the malaria phase. The method used consists of preprocessing, namely cropping the image, segmentation to partition the image's background colour, extraction of morphological features and texture to determine the image value and backpropagation classification to identify the phase of the malaria image. The result of the introduction based on the combination of the two features is $85.56 \%$

\section{Keywords: Preprocessing, Segmentation, Fitur Extraction, Backpropagation}

\section{PENDAHULUAN}

Sampai saat ini malaria masih menjadi masalah kesehatan di seluruh dunia yang mempengaruhi tingginya angka kematian bayi, balita dan ibu hamil [1]. Data Dinas Kesehatan Maluku Utara tahun 2015, memberikan gambaran dari 10 kabupaten dan kota yang ada di Maluku Utara ditemukan kasus malaria klinis sebanyak 24.331 dan positif malaria setelah dilakukan pemeriksaan mikroskopis adalah 2.938 . Hal ini Menunjukan Maluku Utara merupakan daerah yang menyumbang kasus malaria bagi Indonesia. Wilayah di Maluku Utara telah bertekad untuk eliminasi malaria salah satunya adalah Kota Tidore Kepulauan, namun pada tahun 2015 masih ditemukan kasus malaria sebanyak 229 [2]. Diagnosis yang cepat dan akurat infeksi malaria adalah kunci utama untuk mengontrol dan menyembuhkan penyakit ini secara efektif. Saat ini teknik diagnosis berdasarkan pada pemeriksaan mikroskopis slide darah masih tetap menjadi standar utama untuk diagnosis laboratorium malaria [3]. Namun ketelitian dan konsentrasi dalam mengenali parasit malaria hususnya ketiga fase stadium plasmodium yaitu Tropozoit, Scizon dan Gametosit dari sediaan apus darah tergantung pada subyektifitas pengalaman hematologis yang sering menimbulkan persepsi yang berbeda - beda anatara hematologis satu dengan yang lain [4]. Dengan adanya perkembangan pada bidang pengolahan citra medis dan sistem diagnosis yang terbantu komputer, diharapkan dapat mengurangi efek subyekfitas dan membantu dokter dalam proses diagnosis. Tujuan dari penelitian ini adalah membuat alat bantu yang dapat digunakan untuk identifikasi fase dalam sel parasit plasmodium falciparum yang ada pada citra sediaan apus darah berdasarkan morfologi sel darah merah (eritrosit) dengan menggunakan komputer dan konsep pengolahan citra digital, serta artificial intelligent guna standarisasi persepsi keilmuan dan untuk mempercepat waktu analisis. Pada penelitian ini akan dilakukan untuk membandingkan ekstraksi fitur warna dan fitur tekstur yang 
dapat digunakan dalam pengenalan citra sediaan apus darah. Terdapat juga Proses Modified Kmeans clustering yang nanti digunakan untuk memisahkan latar belakang dengan sel eritrosit berdasarkan kernel. Selanjutnnya dilakukan Analisis pengekstrakan ciri guna memberikan prognosis yang ada dalam penelitian ini. Berdasarkan analisis pengekstrakan ciri, JST Backpropagation digunakan untuk proses klasifikasi sel parasit plasmodium falciparum didalam sel eritrosit.

\section{LANDASAN TEORI}

\section{Malaria}

Malaria merupakan salah satu masalah kesehatan masyarakat yang dapat menyebabkan kematian terutama pada kelompok risiko tinggi yaitu bayi, anak balita, ibu hamil. Malaria secara langsung menyebabkan anemia dan dapat menurunkan produktivitas kerja. Penyakit ini juga masih endemis di sebagian besar wilayah Indonesia. Malaria disebabkan oleh parasit darah perifer dari genus Plasmodium. Genus Plasmodium memiliki lima spesies yang dapat menyebabkan infeksi pada manusia yaitu $P$. falciparum, $P$. vivax, $P$. ovale, P. malariae dan P. knowlesi. Setiap plasmodium memiliki fase yakni ring-tropozoit, scizon dan gametosit. Namun diantara kelima spesies tersebut $P$. falciparum adalah yang paling ganas dan sangat mematikan.

\section{Preprocessing}

Tahapan preprocessing adalah langkah awaldalam penyesuaian ukuran citra untuk mendapatkan Region of Interest (RoI) dan peningkatan kualitas citra, penyesuaian ukuran citra bertujuan untuk mencari RoI dengan mempersempit area citra, hal ini untuk mengurangi beban komputasi yang tidak diperlukan dalam mengolah bagian citra yang tidak ada kaitannya dengan obyek yang menjadi fokus dalam penelitian ini [5].

\section{Segmentasi}

Segmentasi adalah membagi suatu citra ke dalam beberapa daerah berdasarkan kesesuaian bentuk/objek. Segmentasi citra menyederhanakan dan merubah representasi citra ke sesuatu yang lebih bermakna dan lebih mudah untuk dianalisis. Segmentasi citra di-gunakan untuk mencari obyek yang ingin di cari dan batas-batas bentuk objek seperti garis, kurva dalam citra. Proses segmentasi akan selesai apabila objek yang diperhatikan dalam aplikasi sudah terisolasi. Algoritma segmentasi secara umum berbasiskan pada salah satu dari 
dua sifat dasar nilai intensitas yakni, diskontinu adalah membagi suatu citra berdasarkan perubahan besar nilai intensitas (seperti sisi), dan similaritas adalah membagi suatu citra berdasarkan similaritas sesuai kriteria tertentu yang sudah didefinisikan [6]

\section{Ekstraksi Fitur}

Ekstraksi fitur merupakan suatu teknik untuk mendapatkan suatu karakteristik dari suatu citra yang mana setiap citra memiliki karakteristik yang berbeda dengan citra yang lain. Ekstraksi fitur menjadi data masukan didalam segmentasi dokumen, sehingga memperkecil perhitungan dalam proses selanjutnya. Tujuan dari ekstraksi fitur adalah untuk mengelompokkan parameter yang mendefinisikan suatu citra dengan keakuratan dan keunikan. Ekstraksi fitur adalah langkah penting untuk memperoleh hasil pengklasifikasian wilayah didalam sistem. Pemilihan metode ekstraksi fitur akan membatasi atau menentukan sifat dan hasil dari langkah preprocessing dan segmentasi.

\section{Klasifikasi}

Proses klasifikasi pada penelitian ini menggunakan metode jaringan syaraf tiruan (JST) adalah paradigma pemrosesan suatu informasi yang terinspirasi oleh sistem sel syaraf biologi. JST dibentuk sebagai generalisasi model matematika dari jaringan syaraf biologi, dengan asumsi bahwa:

1. Pemrosesan informasi terjadi pada banyak elemen sederhana (neuron).

2. Sinyal dikirimkan diantara neuron-neuron melalui penghubung-penghubung.

3. Penghubung antar neuron memiliki bobot yang akan memperkuat atau memperlemah sinyal.

4. Untuk menentukan output, setiap neuron menggunakan fungsi aktivasi (biasanya bukan fungsi linier) yang dikenakan pada jumlahan input yang diterima. Besarnya output ini selanjutnya dibandingkan dengan suatu batas ambang

Hal yang ingin dicapai dengan melatih JST adalah untuk mencapai keseimbangan antara kemampuan memorisasi dan generalisasi. Yang dimaksud kemampuan memorisasi adalah kemampuan JST untuk mengambil kembali secara sempurna sebuah pola yang telah dipelajari. Kemampuan generalisasi adalah kemampuan JST untuk menghasilkan respon yang bisa diterima terhadap pola-pola yang sebelumnya telah dipelajari. Hal ini sangat bermanfaat bila pada suatu 


\section{METODE PENELITIAN}

Ada beberapa metode diagnosis penyakit malaria salah satunya adalah pemeriksaan mikroskopis sediaan apus darah. Pemeriksaan mikroskopis tetap merupakan tes diagnosis utama untuk melihat parasit intraseluler dengan pengecatan Giemsa. Dasar pemeriksaan ini adalah ditemukannya parasit plasmodium pada sediaan darah. Pemeriksaan sediaan darah dengan metode ini relatif murah, tetapi memerlukan tenaga mikroskopis yang terlatih husus dan berpengalaman, waktu yang dibutuhkan untuk mengamati smear darah biasanya berkisar antara 15-20 menit, karena teknik pemeriksaan ini mengandalkan kriteria visual untuk mengidentifikasi berbagai spesies parasit malaria.

Pada penelitian ini, cara identifikasi sel darah merah yang terinfeksi plasmodium falciparum akan diadopsi melalui teknik pengolahan citra digital untuk mengenali sel darah normal, falciparum trofozoit, falciparum scizon dan falciparum gametosit. berdasarkan morfologi dan tekstur seperti pada Gambar 1

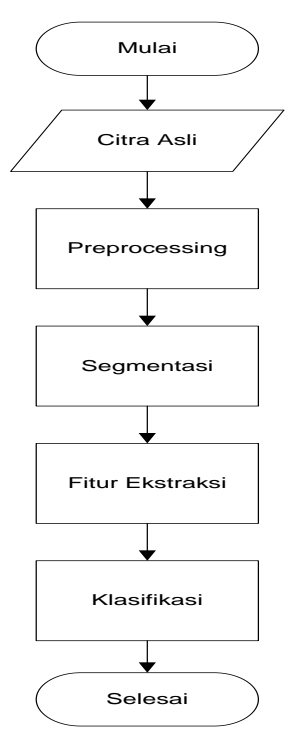

Gambar 1. Rancangan Proses

Gambar 1 menjelaskan bahwa identifikasi sel plasmodium falciparum dengan menggunakan konsep pengolahan citra digital terdapat empat faktor utama diantaranya adalah preeprocessing, segmentasi, dan fitur ektraksi. Citra sediaan apus darah diolah melalui serangkaian teknik tersebut sampai mendapatkan ciri objek. Hasil ekstraksi ciri ini akan menghasilkan nilai-nilai fitur yang dijadikan parameter input untuk proses klasifikasi menggunakan JST Backpropagation.

\section{Alat dan Bahan Penelitian}

Komponen penting yang harus diperhatikan dalam melakukan suatu penelitian adalah alat dan bahan. Berikut rincian alat dan bahan yang akan digunakan dalam penelitian ini:

a. Perangkat lunak 
$\checkmark$ Sistem Operasi : Windows 7

$\checkmark$ Bahasa Pemrograman: Matlab

$\checkmark$ Versi Matlab : R2013a

b. Perangkat keras

$\checkmark$ Processor : Core2 Duo 1.6

Ghz

$\checkmark$ Hardisk : Seagate $500 \mathrm{~Gb}$

$\checkmark$ Ram : 2 x DDR2 2GB

Bahan penelitian adalah data citra digital yang diambil menggunakan DLMA microscope, Infinity-2 digital camera, berukuran 700 X 465 piksel dengan format JPEG

\section{DATA}

citra sediaan sediaan apus darah malaria yang digunakan dalam penelitian ini diperoleh dari RSUD Soa-Siu Kota Tidore Kepulauan dan data tambahan dari public health image library (PHIL)/ phil.cdc.gov

\section{HASIL DAN PEMBAHASAN \\ Preprocessing}

Pada tahap ini, operasi pelembutan citra input bertipe RGB dilakukan perkanal warna untuk menekan komponen yang berfrekuensi tinggi dan meloloskan komponen yang berfrekuensi rendah menggunakan metode Median Filter. Filter median yang digunakan untuk mereduksi noise pada citra input berukuran matriks $3 \times 3$, karena semakin besar ukuran filter maka semakin besar pula informasi pada citra akan ikut hilang. Setelah itu, hasil Median Filter dari masing-masing kanal warna digabungkan kembali untuk diproses selanjutnya.

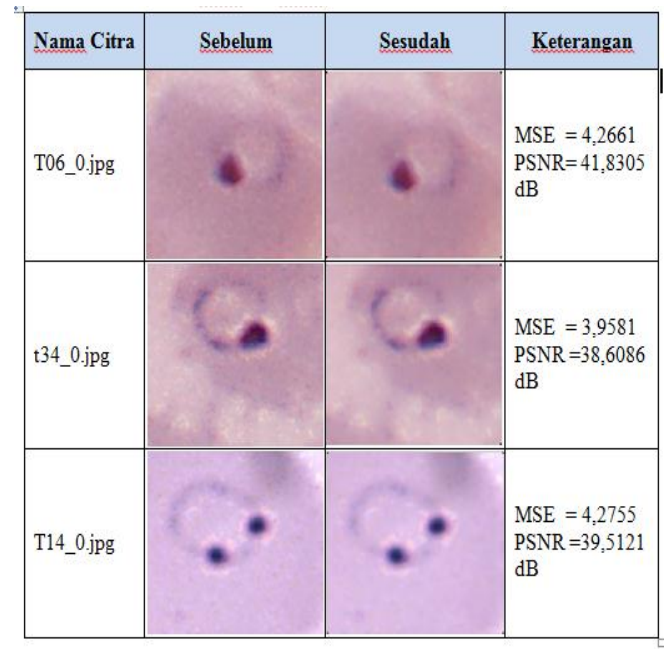

Gambar 2. Hasil Preprocessing

\section{Segmentasi}

Pada tahap segmentasi, terdapat beberapa proses untuk mendapatkan objek inti sel plasmodium falciparum pada sediaan darah merah. Proses pertama untuk mendapatkan objek inti sel plasmodium falciparum adalah citra yang telah difilter dikonversi dari ruang warna RGB ke dalam bentuk ruang warna HSI. Proses tersebut dilakukan untuk menampakkan kemurnian warna dari citra asli, seperti pada Gambar 3 kemudian diekstrak tiap kanal penyusunnya yang kemudian Selanjutnya dilakukan operasi clustering berdasarkan warna-warna dominan menggunakan metode M-KMeans. Setiap citra hasil konversi HSI akan disegmentasi untuk mengelompokkan warna yang dikandung oleh setiap piksel dari 
citra ke beberapa segmen (cluster) dengan jumlah cluster yang sudah ditentukan adalah tiga, untuk memisahkan tiga objek pada citra sediaan apus darah berdasarkan karakteristik warna yaitu objek sel darah merah, parasit inti berwarna biru tua, dan latar berwarna putih. Citra tersebut dihitung berdasarkan jarak euclidean distance sampai didapatkan jarak terdekat yang kemudian dikelompokkan ke masing-masing anggota cluster

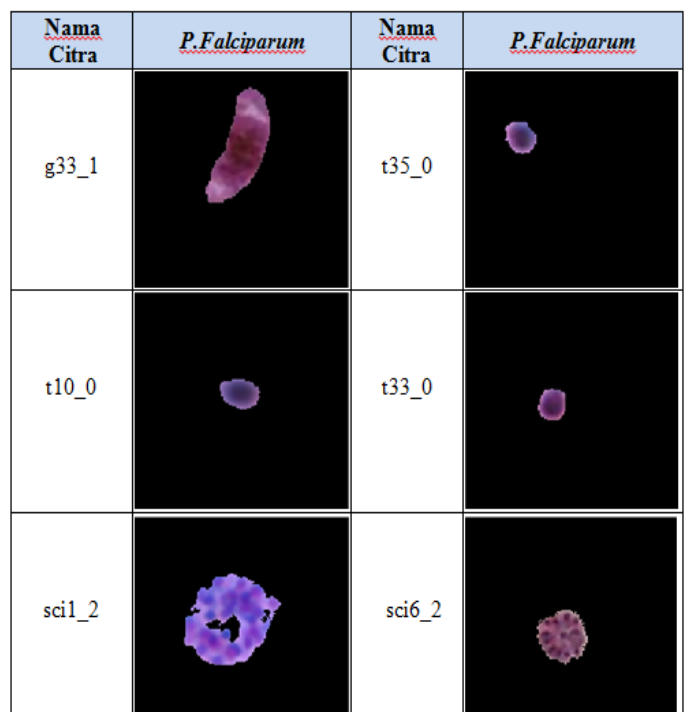

Gambar 3. Hasil segmentasi

Setelah citra disegmentasi, langkah selanjutnya adalah proses post processing dengan menggunakan operasi morfologi untuk menutup daerah objek yang berlubang, proses tersebut terdiri dari region filling, dan operasi erosi untuk menghilangkan piksel-piksel yang bukan termasuk inti sel dari fase plasmodium falciparum kemudian disempurnakan oleh operasi dilasi.

\section{Ekstraksi Fitur}

Citra sediaan apus darah plasmodium falciparum setelah segmentasi diekstrak untuk mendapatkan nilai-nilai fiturnya berdasarkan perhitungan nilai morfologi dan tekstur agar nilainilai fitur yang didapat dari perhitungan tersebut dapat mempermudah dalam proses klasifikasi untuk mengenali citra plasmodium falciparum.

\begin{tabular}{|c|c|c|c|c|c|}
\hline$R_{1} 010$ & 50.5889 & 82.1359 & 1.04286 & .0 .846255 & 2.56034 \\
\hline$G_{-} \times 1 ! 0$ & 34.1543 & 56.405 & 1.13945 & .0 .520841 & 2.6468 \\
\hline B_N1_0 & 45.6254 & 74.7328 & 1.08859 & 0.708632 & 2.63056 \\
\hline $\mathrm{R}_{\mathrm{N}} \mathrm{O} 2 \mathrm{O}$ & 30.9238 & 62.5402 & 1.64334 & 0.945498 & 2.14716 \\
\hline $\mathrm{G} \mathrm{ON} 2 \mathrm{O}$ & 23.2021 & 47.5932 & 1.73638 & 1.3831 & 2.1268 \\
\hline $\mathrm{B} \mathrm{NO} 2_{-}$ & 46.3996 & 91.7552 & 1.47905 & 0.223364 & 1.94138 \\
\hline $\mathrm{R}_{\mathrm{NO}} \mathrm{O} \mathrm{O}$ & 17.1642 & 44.6922 & 2.37105 & 4.05827 & 1.46777 \\
\hline $\mathrm{GrO} 3 \mathrm{O}$ & 8.6953 & 24.6676 & 3.01545 & 8.51505 & 1.4592 \\
\hline $\mathrm{BrO}_{2} \mathrm{O}$ & 13.9965 & 38.298 & 2.70471 & 6.14916 & 1.52169 \\
\hline $\mathrm{R} N \mathrm{O} 4 \mathrm{O}$ & 27.9975 & 69.7448 & 2.12618 & 2.62075 & 1.47525 \\
\hline $\mathrm{GON}_{-}$ & 16.1526 & 42.4908 & 2.54449 & 5.29421 & 1.58248 \\
\hline $\mathrm{BrO}+\mathrm{O}$ & 27.3096 & 68.6819 & 2.19315 & 2.99399 & 1.53614 \\
\hline RNOSO & 33.7104 & 69.1941 & 1.58886 & 0.5843 & 1.84397 \\
\hline GNOSO & 20.9664 & 43.593 & 1.68806 & 1.08774 & 1.8894 \\
\hline $\mathrm{BNOSO}$ & 35.0115 & 72.8661 & 1.67301 & 0.946283 & 1.98569 \\
\hline Rgol!_ & 2.78976 & 18.9606 & 7.1908 & 53.0978 & 0.304152 \\
\hline G gol! & 1.54818 & 10.9897 & 7.94146 & 66.8511 & 0.296124 \\
\hline B gol!1 & 2.82345 & 19.0058 & 6.99066 & 49.3114 & 0.306523 \\
\hline Rgold & 2.40133 & 14.267 & 6.28549 & 40.359 & 0.3852 \\
\hline G g02 1 & 1.28862 & 8.08289 & 7.28137 & 58.2213 & 0.3691 .147 \\
\hline Bgol2! 1 & 2.70811 & 16.1564 & 6.38175 & 42.0665 & 0.384671 \\
\hline Rgoll & 2.16075 & 13.2063 & 6.76947 & 48.5463 & 0.3899 \\
\hline
\end{tabular}

Gambar 4. Hasil ekstraksi fitur

\section{Klasifikasi}

Klasifikasi yang digunakan dalam penelitian ini adalah jaringan backpropagation. Dalam penelitian ini menggunakan dua proses yaitu proses pelatihan dan proses pengujian.

\section{Pelatihan}


Vector input citra yang diperoleh dari fitur warna dan tekstur digunakan untuk proses pelatihan. Tujuan dari pelatihan ini adalah untuk mendapatkan nilai bobot yang menghubungkan ke semua neuron dimana error yang dihasilkan sangat kecil dan mengindikasikan bahwa model jaringan syaraf tiruan tersebut sudah sesuai dengan output. Jika error yang berasal dari pengurangan target dengan keluaran belum memenuhi dengan nilai yang ditentukan maka bobotbobot awal diganti dengan bobotbobot baru. Proses modifikasi bobot ini disebut dengan backpropagation. Pada penelitian ini pelatihan ditujukan untuk mengenal pola-pola citra. Jumlah data pelatihan adalah 120 citra yang terdiri dari 40 citra tropozoit, 40 citra gametosit dan 40 citra scizon. Tingkat tropozoit ditandai dengan angka 0 , tingkat gametosit ditandai dengan angka 1 dan tingkat scizon ditandai dengan angka 2. Parameter yang digunakan untuk pelatihan adalah :
a. Learning rate $(a)=0,01$
b. Hidden layer $=20$ neuron
c. Fungsi aktivasi $=$ sigmoid biner
d. Metode adaptasi = trainlm (Levenberg-Marquardt)
e. Batas epoch diset default (1000 epoch)

Ketiga fase plasmodium falciparum akan dilakukan pengujian berdasarkan bobot yang telah ditentukan, sehingga menghasilkan tingkat pengenalan sebagai berikut :

Tabel 1

Hasil pengujian identifikasi

plasmodium falciparum berdasarkan fitur morfologi

\begin{tabular}{|c|c|c|c|}
\hline \multicolumn{4}{|c|}{ Hasil Identifikasi } \\
\hline \hline & Tropozoit & Scizon & Gametosit \\
\hline Tropozoit & 20 & $0 \%$ & $0 \%$ \\
\hline Scizon & 1 & 17 & 2 \\
\hline Gametosit & 0 & 3 & 17 \\
\hline
\end{tabular}

Tabel 2

Hasil pengujian identifikasi plasmodium falciparum berdasarkan

\begin{tabular}{|c|c|c|c|}
\multicolumn{4}{|c|}{ fitur tekstur } \\
\hline \hline & Tropozoit Identifikasi & Scizon & Gametosit \\
\hline Tropozoit & 11 & 7 & 2 \\
\hline Scizon & 4 & 12 & 4 \\
\hline Gametosit & 6 & 4 & 10 \\
\hline
\end{tabular}

Tabel 3

Hasil pengujian gabungan ekstraksi fitur warna dan gabor filter

\begin{tabular}{|c|c|c|c|}
\hline \multicolumn{4}{|c|}{ Kelas Prediksi } \\
\hline & Tropozoit & Scizon & Gametosit \\
\hline Tropozoit & 20 & 0 & 0 \\
\hline Scizon & 20 & 0 & 0 \\
\hline Gametosit & 0 & 3 & 17 \\
\hline
\end{tabular}

$\mathrm{TP}_{\text {tropozoit }}=20, \mathrm{FP}_{\text {tropozoit }}=0+0=$ $0, \mathrm{FN}_{\text {tropozoit }}=0+0 \quad=0$, $\mathrm{TN}_{\text {tropozoit }}=0+20+3+17=40$

$\mathrm{TP}_{\text {scizon }}=0, \mathrm{FP}_{\text {scizon }}=20+0=$ $20, \mathrm{FN}_{\text {scizon }}=0+3=3$, $\mathrm{TN}_{\text {scizon }}=20+0+0+17=37$

$\mathrm{TP}_{\text {gametosit }}=17, \mathrm{FP}_{\text {gametosit }}=0+3=$ $3, \mathrm{FN}_{\text {gametosit }}=0+0 \quad=0$, $\mathrm{TN}_{\text {gametosit }}=20+0+20+0=40$

\section{Pengujian}


Akurasi $_{\text {tropozoit }}=\frac{20+40}{20+40+0+0} \times 100 \%=$ 100

Akurasi $_{\text {scizon }}=\frac{0+37}{0+37+20+3} \times 100 \%$ $=61,67$

Akurasi $_{\text {gametosit }}=\frac{17+40}{17+40+3+0} \times 100 \%=$ 95

Akurasi rata-rata : $\frac{256,67}{3}=85,56 \%$

Berdasarkan perhitungan dari rata-rata hasil akurasi, terlihat bahwa sistem memiliki keberhasilan sebesar $85,56 \%$ untuk mengenali fase tropozoit, scizon dan gametosit dari citra plasmodium falciparum yang telah dilatih.

\section{KESIMPULAN}

Hasil pengujian dari parameter berupa nilai masukan dari perhitungan fitur morfologi dan perhitungan tekstur yang kemudian di olah pada proses klasifikasi menggunakan jaringan backpropagation dengan data latih dan data uji masing-masing, scizon dikenali tropozoit sebesar 1 citra, scizon dikenali scizon 17 citra, scizon dikenali gametosit 2 citra, gametosit dikenali tropozoit sebesar 0 citra, gametosit dikenali scizon 3 citra, dan gametosit dikenali gametosit adalah 17 fitur tekstur, dimana citra tropozoit yang dikenali tropozoit sebesar 11 citra, tropozoit dikenali scizon 7 citra, tropozoit dikenali gametosit 2 citra, scizon dikenali tropozoit sebesar 4 citra, scizon dikenali scizon 12 citra, scizon dikenali gametosit 4 citra, gametosit dikenali tropozoit sebesar 6 citra, gametosit dikenali scizon 12 citra, dan gametosit dikenali gametosit adalah 10 citra. Gabungan kedua fitur memiliki akurasi sebesar $85,56 \%$.

\section{SARAN}

Berikut ini adalah beberapa saran yang dapat diberikan untuk memperbaiki sistem ini pada penelitian lebih lanjut.

1. Untuk mendapatkan tingkat akurasi dan pengujian yang lebih baik, maka sebaiknya data yang digunakan sebagai data pameter menggunakan data yang lebih banyak lagi.

2. Perlu diteliti menggunakan sediaan darah tebal karena paling banyak digunakan di Rumah Sakit hususnya Indonesia Timur.

\section{DAFTAR PUSTAKA}

[1] World Health Organization (WHO). 2011. Universal Access To Malaria Diagnostic Testing An Operational

Manual. Switzerland: WHO

[2] Rony, Puasa,, Andi, Asrul, H, Arfa, Kader. 2018. Identifikasi Plasmodium Malaria di Desa Beringin Jaya Kecamatan Oba Tengah Kota Tidore Kepulauan. Jurnal Riset Kesehatan 7 (1), 2018, 21 - 24. 
[3] Joel, C., Mouatcho., Golding, D. 2013. Malaria Rapid Diagnostic Tests: Challenges And Prospects. South Afrika: Journal of Medical Microbiology.

[4] Reta,C., Altamirano,L., A, Jesus., Gonzales., Diaz,R.,

Guichard,S.J. 2010. Segmentation of Bone Marrow Cell Images for Morphological Classification of Acute Leukemia. Proceedings of the $23^{\text {rd }} \quad$ International Florida Artificial Intelligence Research Society Conference, USA

[5] I Made Oka Widyantara., dll. 2015. Preeprocessing pada segmentasi citra paru-parudan jantung menggunakan Anisotropic diffusion filter. Teknologi elektro, vol.14, No.2, JuliDesember.

[6] Kadir, A., Susanto,A. 2013. Teori dan Aplikasi Pengolahan Citra. Yogyakarta : Andi 